\title{
Introduction
}

As many universal banks reel from the damage of the global financial crisis 2007-09 and navigate crises such as alleged manipulation of financial benchmarks in the interbank, foreign exchange and precious metals markets, it is an opportune moment to recognise that investment funds and asset managers have become quiet giants in the global financial sector. The fund management sector, which attracts massive global inflows, has become a highly profitable industry in its own right. Fund management is becoming key to liquidity, capital and even credit transformation, ${ }^{1}$ on the basis of its role as investment intermediary between savers and users of capital. Many would argue that the fund management sector has also become a key source of systemic risk for the entire global financial system. ${ }^{2}$

In this book, we examine the fund management sector's role in transforming savings into long-term corporate wealth creation. However, we go further than simply examining the sector's role as a bridge between the providers and users of the economy's surplus funds (important as that activity may be). We are particularly interested in an arguably more profound development: the rise of the sector as the main representative of capital in many developed economies (particularly in the United

1 For e.g., pension funds becoming engaged in direct lending such as mortgages, see 'Dutch Pension Funds Turn Mortgage Lenders', Financial Times (14 Oct 2015); 'Swiss Pension Funds Push into Mortgages', Financial Times (29 Nov 2015) and 'Pension Funds Turn to Mortgage Market in Search for Higher Yield', Financial Times (17 Dec 2015).

2 'SIFI rules to net more asset managers', Financial Times (15 March 2015); Financial Stability Board and the International Organisation of Securities Commissioners, Assessment Methodologies for Identifying Non-Bank Non-Insurer Global Systemically Important Financial Institutions (March 2015). Although the FSB and IOSCO, in Next Steps on the NBNI G-SIFI Assessment Methodologies (4 July 2015), state that the 'systemic label' for asset managers should give way to individual institutional assessment, the FSB has provided guidance as to the aspects asset managers must pay attention to in terms of systemic risk, such as fund liquidity profiles and possible run pressures. See FSB, 'Proposed Policy Recommendations to Address Structural Vulnerabilities from Asset Management Activities' (22 June 2016). 
Kingdom and the United States, but - in an increasingly globalised financial system - in a growing number of other advanced and less developed economies).

In less than three decades, a quiet revolution in corporate ownership has taken place. By becoming major holders of corporate equity, the fund management sector has assumed - almost unnoticed except by specialists and industry participants - a central oversight position astride the corporate governance of a huge range of business enterprises across all sectors and markets. However, in contrast to earlier debates about the merits of public ownership, this is not an ownership revolution that has occurred through conscious policy choices or a public debate about its implications or desirability. Nonetheless, it is a development with subtle but profound implications for the behaviour, competitiveness and performance of underlying economies, and which therefore merits much more careful scrutiny.

Long-term savings funds such as pension funds date back to the post-war period, and as a global phenomenon, the rise of collective savings in pooled vehicles, i.e. investment fund vehicles of various types, is a very marked trend. The rise of the investment management industry is a key aspect of financialisation, i.e. the intermediating of many social needs through the financial economy dominated by the private sector. As key intermediaries of diverse sources of capital, the fund management sector invests in global corporate equity (as well as in other financial assets), carrying out a capital transformation role between savings and long-term corporate wealth creation. This development has been described as 'financier capitalism' ${ }^{3}$ by both critical and sympathetic observers of the sector.

Financier capitalism is not only a myriad of private contracts or mandates for investment amongst private individuals. The scale, the time horizons, and the objectives of saving and investment are all matters of social and public interest. Whether such intermediation will become a successful socio-economic mechanism remains uncertain, as policymakers become aware of the risks that beset the industry - pension deficits, the uncertainties in the vicissitudes of investing in volatile markets, and the unproven capacity of markets alone to resolve social issues such as retirement provision. Furthermore, as we argue in this book, there are significant doubts as to whether the sector can fulfil the

3 Gillian Tett, 'How Savvy Asset Managers can Fend off Regulators', Financial Times (14 May 2015). 
role of "good corporate owner" in a manner that achieves wider economic and social objectives.

However, this scepticism does not appear to be shared currently by many policy makers. An increasing number are vocal in their demand that funds - as the legitimate owners of corporate equity - should play a more engaged role as corporate governance actors. The UK, for example, has led initiatives aimed at "nudging" shareholder behaviour by encouraging institutions to sign up to and comply with a 'Stewardship Code'4 that provides a blueprint for constructive engagement with investee companies as part of institutions' corporate governance role. ${ }^{5}$ This blueprint is being copied in a number of other major economies. ${ }^{6}$ Furthermore, policy initiatives aimed at extending the power of shareholders - over issues ranging from executive pay to approval of significant corporate transactions - are being cut and pasted between jurisdictions as apparent solutions to many of the problems of modern corporate governance. We are sceptical about the likely efficacy of enhancing shareholder power and engagement. Our scepticism is based on the fundamental challenges faced by fund management in reconciling a constructive corporate ownership role with their own business and regulatory objectives.

Indeed, one of the main objectives of this book is to demonstrate that the way in which the investment management industry approaches its corporate governance responsibilities vis-à-vis investee companies is a

4 See Stewardship Code 2014, https://www.frc.org.uk/Our-Work/CodesStandards/Corporate-governance/UK-Stewardship-Code.aspx, also see discussion in Iris H-Y Chiu, "Turning Institutional Investors into "Stewards" - Exploring the Meaning and Objectives in "Stewardship" (2013) Current Legal Problems 1.

5 The UK has promulgated the first Stewardship Code for institutional investors, geared towards greater engagement in the corporate governance of their investee companies, Stewardship Code 2010, 2012, and discussed in Chapter 3. Many jurisdictions have adapted the UK Code in different ways and for different purposes, and the EU's Shareholder Rights Directive 2017 that will attempt to 'legalise' the concept of shareholder stewardship is at present the most far-reaching measure. See generally, Iris H-Y Chiu, 'Learning from the UK in the Proposed Shareholders' Rights Directive 2014? European Corporate Governance Regulation from a UK Perspective' (2015) 114 ZVgIRWiss forthcoming.

6 For example the Stewardship Code introduced by the Japanese securities regulator, see http://www.fsa.go.jp/en/refer/councils/stewardship/20140407/01. pdf. The Italian borsa has also embarked on an initiative to introduce such a code, see http://www.borsaitaliana.it/comitato-corporate-governance/news/20130 306.en.pdf, and Denmark is the most recent jurisdiction to adopt such a code, see https://corporategovernance.dk/sites/default/files/media/anbefalinger_for_aktivt_ ejerskab.pdf. 
direct consequence of its own internal business models, commercial imperatives and regulatory constraints. The narrow interests of the sector are not necessarily aligned with the longer-term flourishing of investee companies or the role of the latter in building broader economic competitiveness. As a result, it is justifiable to question recent trends aimed at 'shareholder empowerment' or 'shareholder activism' as an underpinning of economic reform.

Despite the enthusiasm for shareholder empowerment at the policy level, there has been some recognition of the deficiencies in funds' corporate governance capacities, especially in the wake of the global financial crisis. ${ }^{7}$ It is commonly observed that many institutional shareholders seem disengaged from 'monitoring' risky corporate practices and often encourage short-term oriented corporate practices as a means of underpinning near term equity prices. ${ }^{8}$ Furthermore, a significant causal connection between corporate performance and institutional shareholder engagement has yet to be demonstrated by rigorous empirical research. ${ }^{9}$ As we will observe in this book, investors' corporate governance activities are a relatively unimportant and ineffective instrument in the context of their overall investment management strategy, and give rise to both positive and negative externalities under different circumstances. ${ }^{10}$ Hence, we are of the view that extending regulatory governance over certain aspects of investors' corporate governance roles is not an illfounded suggestion.

This book therefore provides an account of investment management in terms of how it is structured and governed, in order to highlight how its corporate governance role in the wider economy ought to be understood. We call this the 'governance nexus' between the fund management sector

7 See discussion in Iris H-Y Chiu, 'Reviving Shareholder Stewardship: Critically Examining the Impact of Corporate Transparency Reforms in the UK' (2014) 38 Delaware Journal of Corporate Law 983.

8 Lucian Bebchuk and Holger Spamann, 'Regulating Bankers' Pay' (2010) 98 Georgetown Law Journal 247; Peter O Mülbert, 'Corporate Governance of Banks after the Financial Crisis: Theory, Evidence, Reforms' (ECGI Working Paper 2010).

9 E.g. see Sunil Wahal, 'Pension Fund Activism and Firm Performance' (1996) 31 Journal of Financial and Quantitative Analysis 1; Jonathan M Karpoff, 'The Impact of Shareholder Activism in Target Companies: A Survey of Empirical Findings' (Sep 2001) at http://papers.ssrn.com/sol3/papers.cfm? abstract_id=885365.

10 E.g. see Mette Neville, 'The Suspicious Shareholder' in Hanne Birkmose, Mette Neville \& Karsten Engsig Sørensen (eds.), The European Financial Market in Transition (Alpen aan den Rijn: Kluwer Law International, 2011). 
and the corporate sector, and we argue that studying the 'governance nexus' allows us to understand the achievements and limitations of such instrumental assumptions of corporate governance roles by funds. We draw wider implications for the social and policy expectations of what can be achieved by funds' corporate governance role in the wider economy.

Based on the above, it is perhaps unsurprising that we are not as sanguine about the potential role of the fund management sector as an agent of capitalist transformation, as described in earlier literature such as Useem's investor capitalism, ${ }^{11}$ or Hawley and Williams' concept of 'fiduciary capitalism'. ${ }^{12}$ Both concepts treat the fund management sector as fiduciary intermediaries that bring together the collective power of savers in influencing the governance of the corporate sector. According to this perspective, the connection between savers in the Main Street and corporate giants will pave the way for corporate governance to be shaped in a democratic manner, having a benign and profound impact on the wealth-creating role of the corporate sector for the real economy for the long term. As the UK Kay Review puts it,

[t]he long term public goal for equity markets is in securing the public purposes of high performing companies and strong returns to savers through an effective asset management industry, and in ensuring that the profits earned by companies are as far as possible translated into returns to beneficiaries by minimising the costs of intermediation. ${ }^{13}$

A realistic assessment of the role of institutional investors to date shows that, by and large, the fund management sector has yet to play this anticipated role in shaping the governance of the corporate sector. Although fund management has been growing relentlessly, with savings pouring in from pension savers in developed countries, current account surpluses in emerging economies and private wealthy individuals, such financialisation ${ }^{14}$ of savings into investment has not typically been used to promote corporate governance that favours long-term value creation or economic competitiveness. The financial intermediaries that make up and

11 Michael Useem, Investor Capitalism: How Money Managers are Rewriting the Rules of Corporate America (Basic Books, 1999).

12 James P Hawley and Andrew T Williams, The Rise of Fiduciary Capitalism: How Institutional Investors Can Make Corporate America More Democratic (Penn: University of Pennsylvania Press 2000).

13 BIS, The Kay Review of UK Equity Markets and Long-Term Decision Making (Interim Report, Feb 2012), see the Foreword of the Final Report, 23 July 2012.

14 To be discussed in detail in Chapter 1. 
support the fund management sector have focused on value arbitrage through trading and the generation of rents through excessive transactionalisation. ${ }^{15}$ From a governance perspective, the sector has been largely behaving as passive rentiers; such behaviour matches the pattern anticipated by Berle and Means ${ }^{16}$ in the 1930s, who rightly predicted that such an approach would characterise the investment behaviour of minority shareholders in an economy with a highly dispersed corporate ownership structure. Although these early trends are changing with the arrival of some degree of shareholder activism or engagement, ${ }^{17}$ this is also problematic for long-term value creation due to fund management's overriding need to generate short-term financial performance as a means of fulfilling its own business objectives. We do not blithely accept the assumed alignment of funds' shareholder roles with the public interest in securing a well-performing corporate sector in the UK for the long term. Indeed there may be a case for more public-interest oriented regulatory governance over funds' shareholder roles, which are intrinsically bound up in their internal governance, structures and incentives.

We examine the governance, structures and incentives for major investment fund vehicles in this book, and are of the view that these are shaped by market forces and, increasingly, regulatory law. These forces, sometimes contradictory in nature, shape funds' internal governance and incentives. In particular, investment law and regulation endorse certain economic concepts such as modern portfolio management theory, and require regular accountability regarding financial performance and the provision of reasonably certain liquidity in the name of investor protection. These have become crucial to shaping the structures and incentives of investment funds. ${ }^{18}$

15 To be discussed in Chapter 1.

16 The separation of ownership from control was described by Berle and Means as the 'atomisation of property'. They observed that as shareholding in a corporation became diffuse, fragmentation into smaller holdings occurred as corporations grew. Shareholders became passive, leaving decision-making in the hands of managers. This phenomenon was described as a separation of the spiritual values of ownership from the ownership of stock, see Adolf A Berle and Gardiner C Means, The Modern Corporation and Private Property (1932, Transaction Publishers, 1999 edn) at p. 66.

17 See Iris H-Y Chiu, The Foundations and Anatomy of Shareholder Activism (Oxford: Hart 2010); D Katelouzou, 'Worldwide Hedge Fund Activism: Dimensions and Legal Determinants' (2015) 17 University of Pennsylvania Law Review 789; 'Shareholder Activism Catches Fire in Japan', Financial Times (22 June 2014).

18 To be discussed in Chapter 2. 
Law and regulation are premised on meeting the needs of private accountability in investment mandates, and we are of the view that such an emphasis to an extent contradicts the social and wider economic governance dimensions of the funds phenomenon. As such, we highlight where the structures and incentives of investment funds shaped by market forces, law and regulation create dilemmas in fulfilling ultimate social objectives in saving, and also result in dysfunction in the corporate ownership practices of funds. These dilemmas and dysfunctions, arising through the intersection of private interests, market forces and public policy, give rise to the increasingly unsatisfactory role played by funds at the centre of our corporate governance system.

The requirements of regular accountability and reasonable liquidity are derived from market needs and regulatory law, and they often conflict with the long-term nature of some savings. These will be fleshed out further in Chapter 2. Such requirements on the one hand mitigate the 'agency' problem in investment intermediation, but on the other hand create incentives to compromise long-term investment objectives in favour of the inducement of short-term performance. Such short-termist objectives could in some cases generate more cost in the long term, and at worst could create dysfunctions that cause the long-term objectives to be lost sight of. In the delicate balance of the 'governance nexus' which is shaped by the interaction of various private law and public regulatory regimes, the introduction of the 'Stewardship Code' which narrowly focuses on funds' corporate governance roles may be too myopic and fail to address the incentives arising from funds' underlying business models. Indeed, the call to stewardship may give rise to new forms of financier capitalism known as shareholder activism, ${ }^{19}$ stewardship $^{20}$ or engagement ${ }^{21}$ that could create new issues of concern.

19 A more American term that has evolved from the activism of pension funds such as CalPERS to modern day hedge fund activism, see Chapters 2-4, Iris H-Y Chiu, The Foundations and Anatomy of Shareholder Activism (Oxford: Hart 2010).

20 UK parlance, see the UK Stewardship Code 2010, 2012, https://www. frc.org.uk/Our-Work/Codes-Standards/Corporate-governance/UK-StewardshipCode.aspx; also Iris H-Y Chiu, "Turning Institutional Investors into "Stewards" Exploring the Meaning and Objectives of "Stewardship"" (2013) Current Legal Problems 1.

21 Used in the European Shareholder Rights Directive 2017, Article 3g, Directive (EU) 2017/828 of the European Parliament and of the Council of 17 May 2017 amending Directive 2007/36/EC as regards the encouragement of long-term shareholder engagement. 
In sum, this book explores how funds and their asset managers are governed in terms of their investment management business models and regulatory constraints, and explains how their corporate governance roles in the wider economy are essentially derived from that rubric. We highlight wider implications for our understanding of investment funds' intermediating role between the private needs of investment and the social needs of saving. We argue that funds' instrumental assumption of corporate governance roles, which is borne out by our study of the 'governance nexus', is not a panacea for the social concerns of long-term corporate wealth creation in order to deliver savings needs and a competitive corporate economy. Indeed, encouraging the corporate governance role of fund management would only highlight the divergence in the interests of fund management as a business activity and the ideals embodied in shareholder stewardship across the economy as a whole. We are of the view that this divergence needs to be recognised and that if it is to be bridged, much more far-reaching policy and regulatory reforms would need to be introduced.

We will discuss the major fund vehicles in pensions, mutual, alternative investment and sovereign wealth management. We argue that the context of financialisation and the legal and regulatory structures which have developed in response are critical to understanding how modern investment management works for many fund vehicles and their asset managers. For example, why do the funds that seem to be most democratically representative, such as pensions and mutual funds, suffer from chronic short termism in their investment behaviour? We also argue that the character of activism, engagement or stewardship demonstrated by institutional investors and their asset managers may be far from producing beneficial effects for long-term corporate wealth creation. Policy-makers are therefore advised to be more cautious about promoting the beneficial effects of shareholder engagement, activism or stewardship.

\section{SCOPE AND COVERAGE OF THE BOOK}

The book comprises two parts. In Part One, there are three chapters featuring general discussions and themes relating to fund structures, incentives and governance and how they affect the corporate governance role of equity-owning fund entities and their delegates. Part Two then provides more detailed treatment of key investment fund entities from Chapters 4 to 8 .

Chapter 1 deals with the rise of the investment fund industry to intermediate savings and investment. This phenomenon is often known as 
financialisation. We discuss the key characteristics of such financialisation as a broad context for understanding the nature of investment management.

Chapter 2 discusses our high-level perspectives on the structures and incentives of the fund management industry. We explore common main themes that pertain to all funds, such as how law and regulation shape short-termist tendencies in the name of investor protection, and how the context of search for yield and liquidity in the financialised environment shapes investment management practices. The investment intermediation business also comprises chains of specialist services, in particular, the services of asset managers and investment consultants. We also explore the inter-relationships within the chains as economic and legal institutions. Chapter 3 then discusses our high level perspectives on the relationship between investment management and the corporate governance roles assumed by equity-owning fund entities and their delegates. In drawing out the 'governance nexus', we will critically appraise the nature of such corporate governance roles and their wider implications for long-term corporate wealth creation. In particular, we argue that caution needs to be exercised in unequivocally endorsing 'stewardship', 'activism' or 'engagement' as the appropriate corporate governance role for funds.

Chapters 4 to 8 provide detailed treatment of key equity owning investment fund entities. We explore how specific aspects of their internal governance, structures and incentives affect their corporate governance roles in different ways. Chapter 4 deals with public and private sector pension funds, Chapter 5 deals with retail collective investment schemes, Chapter 6 deals with hedge funds, Chapter 7 with private equity funds and Chapter 8 deals with sovereign wealth funds. Chapter 9 draws together the analyses in the book and provides brief concluding remarks.

The financialised intermediation of savings for investment is not a panacea for the social dimension of savings needs. Law, regulation and corporate governance practices highlight the broader dilemmas, contests of objectives and interests in the phenomenon of investment management, as it is conceived of in private and public paradigms. This book plays a part in highlighting where such dilemmas and contests lie, by examining the corporate governance roles of equity-owning funds as part of their investment management. We argue that the analysis of the governance nexus provides important insights in the nature of investment management, which, in a financialised era, should be broadly investigated in terms of its promises, sub-optimalities and governance implications. 